\title{
The Finnish Road Weather Business Ecosystem - Turning Societal Benefits into Business and the Other Way Round
}

\author{
Pekka Leviäkangas ${ }^{1}$, Aki Aapaoja ${ }^{1}$, Tuomo Kinnunen ${ }^{1}$, Eetu Pilli-Sihvola ${ }^{2}$, Raine Hautala ${ }^{2} \&$ Zulkarnain $^{2}$ \\ ${ }^{1}$ Industrial Engineering and Management, University of Oulu, Oulu, Finland \\ ${ }^{2}$ VTT Technical Research Centre of Finland, Espoo, Finland \\ Correspondence: Zulkarnain, VTT Technical Research Centre of Finland, Kaitoväylä 1, P.O. Box 1100, FI-90571 \\ Oulu, Finland. Tel: 358-20-722-2018. E-mail: zulkarnain@vtt.fi
}

Received: January 30, 2014 Accepted: February 25, 2014 Online Published: March 19, 2014

doi:10.5539/emr.v3n1p56

URL: http://dx.doi.org/10.5539/emr.v3n1p56

\begin{abstract}
This paper investigates the winter road maintenance ecosystem in Finland and discusses its importance in ensuring mobility. The ecosystem model is illustrated using the Customer Value Chain Analysis (CVCA) tool and is constructed based on publicly available material and direct information from stakeholders. The model describes the roles and functions of stakeholders and their value network. With the help of the model, further analysis based on value analysis and value theory is conducted to evaluate the current ecosystem. The service and product offerings of individual stakeholders are isolated and described in more detail. The main idea is to show how individual offerings can supplement each other in the process of value co-creation. To enhance and co-create value, collaborative development of the ecosystem is perceived as the best value capturing strategy.
\end{abstract}

Keywords: road maintenance, winter, ecosystem, value co-creation, value analysis

\section{Introduction and Aims}

Our mobility system serves multiple critical functions of our society. The moving of people and goods needs to be ensured not only in everyday circumstances but also in harsher and more exceptional conditions. Weather and infrastructure availability go hand in hand; different weather phenomena affect the transport environment and infrastructure in terms of safety, reliability and accessibility. Recent research findings show that the impacts of weather are quite significant (see e.g. Leviäkangas et al., 2013; Molarius et al., 2013). In the Northern Hemisphere, winter poses radical challenges to mobility and transport.

In winter, surface land transport infrastructures including roads and railways must be kept in usable condition. Snow must be removed and ice melted or treated, and road users, travellers and transport operators must be made aware of the condition and availability of their route and modal choices. Maintenance service providers carry out these operations at the request of infrastructure owners, which usually are national or local road authorities and railway companies or agencies.

Over the past two or three decades, public sector infrastructure managers have unbundled their functions, with a widening specter of services related to maintenance and construction of transport infrastructures being outsourced to the private sector, while ownership of the infrastructure and ultimate responsibility for it has remained with the public sector (Leviäkangas et al., 2011). Hence a capable and resourceful service provider network has become an increasingly vital resource for communities and societies in ensuring that basic functions, such as mobility, perform seamlessly and efficiently.

Here we discuss the importance of such a service and technology provider network, which we regard as an ecosystem, in the ensuring of mobility. We focus on winter maintenance of the road network and show how this ecosystem is built in Finland to provide safety, reliability and accessibility of roads, first to infrastructure managers/owners and ultimately - and in particular - to road users. We further discuss and argue that such ecosystems that form a part of critical societal functions are one of the competitiveness parameters of any community, society or country. Unless these ecosystems are made to work effectively, the functions of society will underperform and efficiency losses will materialize.

The purpose of this paper is to model the Finnish road weather ecosystem using systems and value engineering tools in describing the roles of different stakeholders within the ecosystem. Finally, we present some conclusions 
on the examination of the ecosystem.

\section{Method and Process of Analysis}

To understand the current state of the Finnish winter road maintenance business ecosystem, our study applies the approach of systems theory. An ecosystem is, after all, clearly and by definition a system comprising multiple actors having inter-relationships between each other and the environment. Business ecosystems are characterized by a large number of loosely interconnected participants who depend on each other for their mutual effectiveness and survival (Peltoniemi, 2006). System thinking is a framework for problem solving that considers problems in a holistic manner and attempts to enhance the understanding of, and responsiveness to, the problem (Rubenstein-Montano et al., 2001). Outcomes from systems thinking depend heavily on how a system is defined, because system thinking examines relationships between the various parts of the system. Boundaries must be set to distinguish what parts of the world are contained inside the system and what parts are considered the environment of the system (e.g. internal and external stakeholders). The environment of the system will influence problem solving because it influences the system, but it is not part of the system (Rubenstein-Montano et al., 2001). Hence, business ecosystems are considered as systems with economic, social and technological aspects. Different tools can be used to present complex systems: diagrams, flow charts, morphological boxes, etc. (see e.g. Ritchey, 2002; Yourdon, 2012)

The ecosystem model is illustrated using Customer Value Chain Analysis (CVCA), which "is an original methodological tool that enables design teams in the product definition phase to comprehensively identify pertinent stakeholders, their relationships with each other, and their role in the product's life cycle." (Donaldson et al., 2006) The tool has mainly been used in the context of product development, where it extends the functionality and utility of the customer supply chain by requiring designers to study the value relationships, or value propositions, between the various participants (Donaldson et al., 2006). This study applies CVCA to the road weather ecosystem, and in our analysis, CVCA is used to first to draw the model of the ecosystem itself; secondly to evaluate and analyze the current ecosystem and to isolate the service and product offerings of individual stakeholders. The main idea is to show how individual offerings can supplement each other in the process of value co-creation.

The description of the winter maintenance ecosystem model is based partly on publicly available material (annual reports of companies, other reports and printed materials), but also largely on direct information from stakeholders. The analysis is part of the FIRWE (Finnish Road Weather Excellence) research project funded by the Finnish Technology Agency. The process of creating and validating the ecosystem model comprised a series of meetings and workshops held as part of the research in 2012-2013. The drafting was done by the researchers based on publicly available material, and the validation was performed in two workshops (3-4 hours each) attended by four ecosystem members (maintenance equipment manufacturer; vehicle location, measurement and tracking solutions provider; meteorological device manufacturer; and road weather and conditions forecast provider).

The background and theoretical foundations were laid on the basis of literature studies and deskwork. The ecosystem analysis is further based on value analysis and value theory. The attempt is to show that the functions performed by the ecosystem increase the value of the output, and that the value is greater than the sum of the functions as individual activities by individual actors (referred to here as stakeholders). In plain words, the ecosystem can provide value (benefits) to the customers of winter road maintenance, based on the supplementary skills and activities of service suppliers that build the supply side of the ecosystem.

Value is defined by the Society of American Value Engineers (SAVE International, 2007) as follows:

$$
\text { Value } \approx \frac{\text { Function }}{\text { Resources }}
$$

Value is formed when the desired functions are performed or delivered using resources in terms of money, time, materials, etc. When this principle is applied to service supply chains, i.e. value networks that deliver service rather than individual functions, we can state (see Leviäkangas \& Hietajärvi, 2010) the following:

$$
\text { Value of service } \approx \frac{\text { Function } 1}{\text { Resources } 1}+\frac{\text { Function } 2}{\text { Resources } 2}+\frac{\text { Function } 3}{\text { Resources } 3}=\frac{\text { Service }}{\text { Resources } 1+2+3}
$$

In essence, the above conceptual value model (where functions and resources can run up to $\mathrm{n}$ in order to build the service aspired to) describes the philosophy of ecosystems providing services that have value to the users by 
combining their resources and functions. Resources must be understood not only as costs of delivering a function but also as technologies, capabilities, distribution networks, market presence, and so forth. The list can be whatever the particular context may define as a resource. For example, in an ecosystem a small company offering unique technology may enable a service that would not be possible without it; or for some ecosystems a customer base managed by one company will enable the ecosystem to widen its customer base and increase sales revenues for all stakeholders within the ecosystem.

As we proceed with our analysis, the principles of value and value chain analytics principles become evident. We distinguish between the different functions (service and product offerings) of the ecosystem stakeholders in a value network and discuss the end-user value, which in fact becomes a socio-economic benefit that justifies performing the functions in the ecosystem. We also discuss the challenge of transforming this socio-economic benefit into tangible cash flows expected by the supply side of the ecosystem.

Depending on how we define the ecosystem, we can either have the supply side, i.e. the pure business ecosystem comprising companies with their offerings, or we can have the entire ecosystem with both the supply and demand side. We adopt the latter approach, with the resulting considerations between the dynamics of the two sides.

\section{How Ecosystems Are Building a Competitive Advantage}

\subsection{Business Ecosystems}

A business ecosystem is an economic community supported by a foundation of interacting organizations and participants. In ecosystems, participants can co-evolve capabilities around new innovations by collaborating to support new offerings, satisfy customer needs and eventually discover innovations (Moore, 1993). Iansiti and Levien (2004b) have described business ecosystems as "loose networks - of suppliers, distributors, outsourcing firms, makers of related products or services, technology providers, and a host of other organizations - that affect and are affected by the creation and delivery of a company's own offerings." In other words, ecosystems include a large number of loosely interconnected participants who depend on each other for their mutual effectiveness and survival (Iansiti \& Levien, 2004a). In this study, the participants of ecosystems are called stakeholders. A stakeholder is any organization in the ecosystem that can affect or is affected by the achievement of the ecosystem's objectives (Freeman, 1984). Typically the stakeholders are further divided into internal and external. Internal stakeholders are direct members of the ecosystems and hence have a clear role in them. External stakeholders are not formal members of the ecosystem, but may have an impact or are impacted by the ecosystem (Winch \& Bonke, 2004; Cleland, 1986).

\subsection{From Value Creation towards Value Co-creation}

The ultimate purpose for a buyer and seller engaging in a relationship is to work together in a way that creates value for them. Walter et al. (2001) have defined value "as the perceived trade-off between multiple benefits and sacrifices gained through a customer relationship by key decision makers in the supplier's organization. Those benefits and sacrifices can result from the relationship under question as well as from connected relationships on which the focal relationship has an impact or is impacted by those other relationships."

Value creation should always be a win-win situation and the supplier needs to offer value to the customer but also needs to gain benefits from the customer (Walter et al., 2001). Therefore, in the current value chains, stakeholders no longer solely create value and thus wish to insert themselves into the chain and open up the possibility of contributing to value creation with their own activities. Ramaswamy and Gouillart (2010) have called this situation value co-creation. It is about redefining the process and methods, and redefining how organizations involve stakeholders by bringing them into the value stream and value creation process and involving them in it. Basically, value co-creation adds to project stakeholder collaboration and at the same time shifts the mindset from a traditional "subsystem delivery" to "system ensemble and experience co-creation."

Another view of value co-creation is the dual division between supply and demand. Typically business ecosystems combine their offerings in order to better meet customers' expectations and aspirations. Likewise, the lowering of the threshold between customers and suppliers can lead to closer co-operation between the demand and supply sides, where mutual benefits can be realized - suppliers having a better understanding of their customers' needs and customers gaining better service and enhanced value for their money. The demand-supply divide follows the division between the public and private sectors (see Figure 1) and the most effective positioning of the divide has been under very active debate during the last two to three decades in the context of new public management (see e.g. Gruening, 2001). One of the embodiments of co-creation between the public and private sectors is public-private partnerships (PPP). Also PPPs have been studied to a vast extent in all 
sectors of societal functions, but perhaps mostly within the transport sector, which makes it a noteworthy concept with regard to winter road management as well, albeit the fact that PPPs are mainly encountered as applications to procure and finance capital projects (see e.g. Leviäkangas \& Ojala, 2010).

The trend of moving from value creation towards value co-creation perfectly matches the idea of developing the business ecosystem of Finnish road winter maintenance. At the moment, the value creation processes of both firms and stakeholders are mainly focused on their own products and services. Hence the synergistic benefits and values that could be co-created by working together in an ecosystem have not yet been defined, and there are no systematic ways of managing the ecosystem. However, the stakeholders in the Finnish road winter maintenance ecosystem have shown an interest in starting to develop the current value chain and their offerings towards a well-defined ecosystem, which identifies its capabilities and values in order to create efficient and safe "winter mobility markets".

Value creation or co-creation itself comprises three compelling phases: value identification, value proposition and value delivery (Murman \& Allen, 2002). In the first phase, the stakeholders and their values, needs and offerings are identified, followed by the value propositions that combine values, needs and offerings into collective purposes and objectives. Customer and external stakeholder perspectives of value are often understood more or less differently, and seeking a consensus is further complicated by the stakeholders' (both internal and external) disparate revenue logic. Therefore careful consensus building and effective delivery processes are needed to merge the diverse needs and objectives. The complexity and disparate value perceptions are very common in service delivery value networks, and are typically encountered in information-intensive services as described by Leviäkangas (2011) and Herrala et al. (2009).

\subsection{Ecosystem Dynamics}

There is a deeper dynamics between ecosystem stakeholders, regardless of their positioning or role within the ecosystem. Weiller \& Neely (2013) correctly identify that on the supply side of the ecosystem, the business models of individual companies partly depend on the ecosystem they are working in, but affect it at the same time. Hence the ecosystems are dynamic in terms of evolution phase (time) and content (composition and operating modes and business models of the members). Early stage ecosystems (usually smaller and consisting of smaller companies) change as the key stakeholders change their business models. Exit or entry of stakeholders likewise changes the logic, structure and operating and/or business models of remaining ecosystem members, unless there is a perfect substitute to fill the empty position or the entrant is merely replacing a leaving member.

The fewer vital key members there are in the ecosystem, the more vulnerable it becomes in terms of entry and exit of these particular members, as substitutes may be difficult to find or non-existent. On the other hand, the internal dynamics of the ecosystem becomes simpler and more straightforward when the number of members is limited. At the same time, yet, the interdependency between the members increases. Simplicity may also be a strength, especially in the early evolutionary phase of the ecosystem, or when the market size in which the ecosystem is operating is limited. The topological structures of ecosystems are probably of a wide variety, but state-of-the-art industry structure analysis tools can be used, for example when measuring the concentration of market power and size (see e.g. Zulkarnain \& Leviäkangas, 2012 for an analysis of the intelligent transport systems industry in Finland).

\section{Winter Maintenance Ecosystem}

\subsection{A Generic Model}

The question of how winter maintenance services can be turned into societal benefits in a way that brings value both to the supply and demand sides of the ecosystem can be described as a traditional value chain. The offerings (i.e. functions) of supply side technology, component, system, service and value-added service providers are 'packaged' into services that are demanded by end users. Not only does the supply side comprise a value chain, but so does the demand side; road authorities acting on behalf of road users, for instance, may have certain functions that add to the value of end-user services. Public information on road conditions, management and control functions in maintenance operations are examples of such 'services' provided to road users.

The divide between supply and demand is not fixed. As policy changes in infrastructure management have increasingly shifted the responsibility, at least in operational terms, to the private sector, the dividing line has been shifting from left to right (see Figure 1), reducing the role of the public sector. Another change could be forced by technology, and is the case here where information and communications technology (ICT) has played a huge role in recent years. The ICT enabler has pressed the public sector into redefining its role in many functions, not only those concerning winter maintenance. While the sole enabling factor has been only one motivation, the 
capability of the public sector to manage this change has probably been equally important. Where enablers are not mastered and there is not enough capability to govern the new situation, the obvious answer has been to shift part of the responsibility onto the private sector (Leviäkangas \& Hietajärvi, 2010).

The obvious conclusion is that the ecosystems may be highly unstable if technology and policy changes are affecting the environment they operate in.

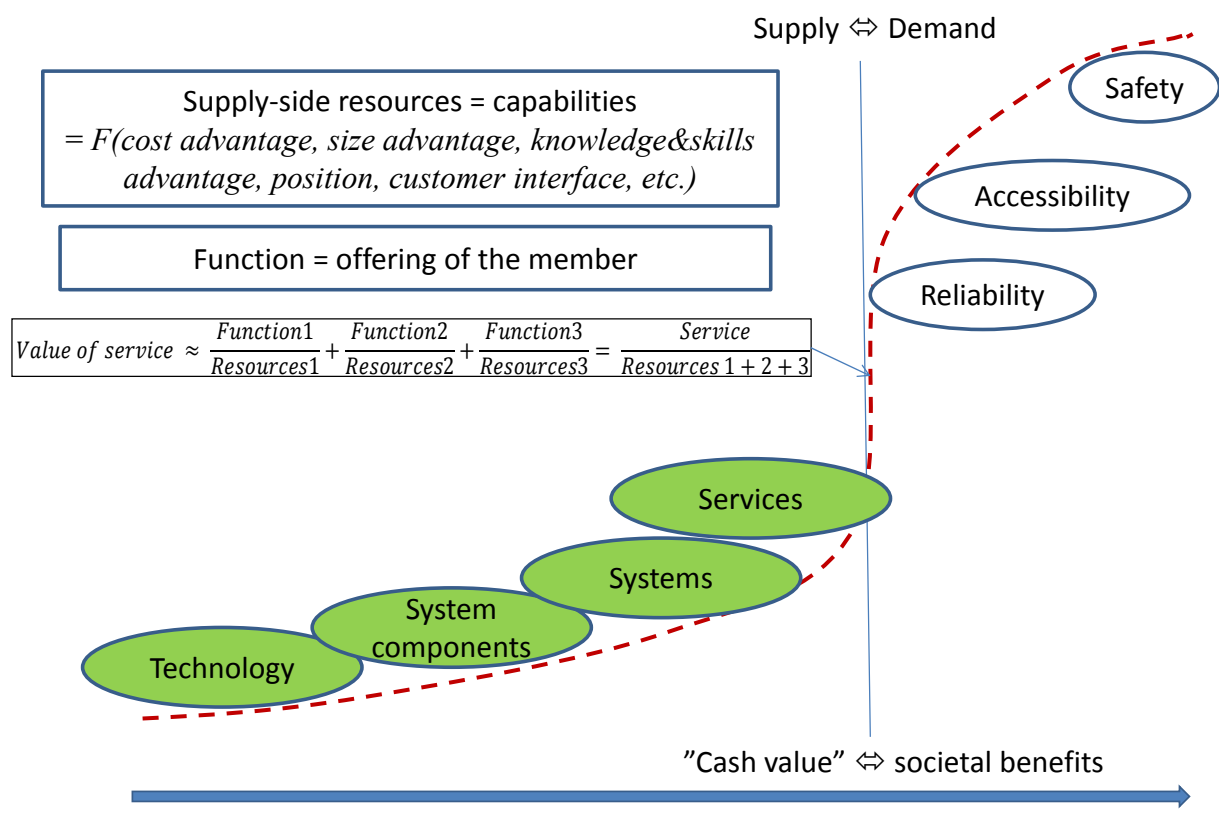

Value added

Figure 1. The ecosystem value creation process

\subsection{The Current Finnish Winter Maintenance Ecosystem}

The ecosystem of road maintenance in Finland is built around three types of roads: state-owned highways and other public roads, municipal streets, and private roads. All stakeholders represent some function connected to these three types of roads. The main purpose and objective of the ecosystem is to provide safe and fluent road conditions for traffic and end users, including private, commercial and other professional traffic.

Figure 2 illustrates the current perception of the Finnish winter road maintenance ecosystem and the value network. Additionally, Table 1 lists the stakeholders and their role and offerings in more detail. 


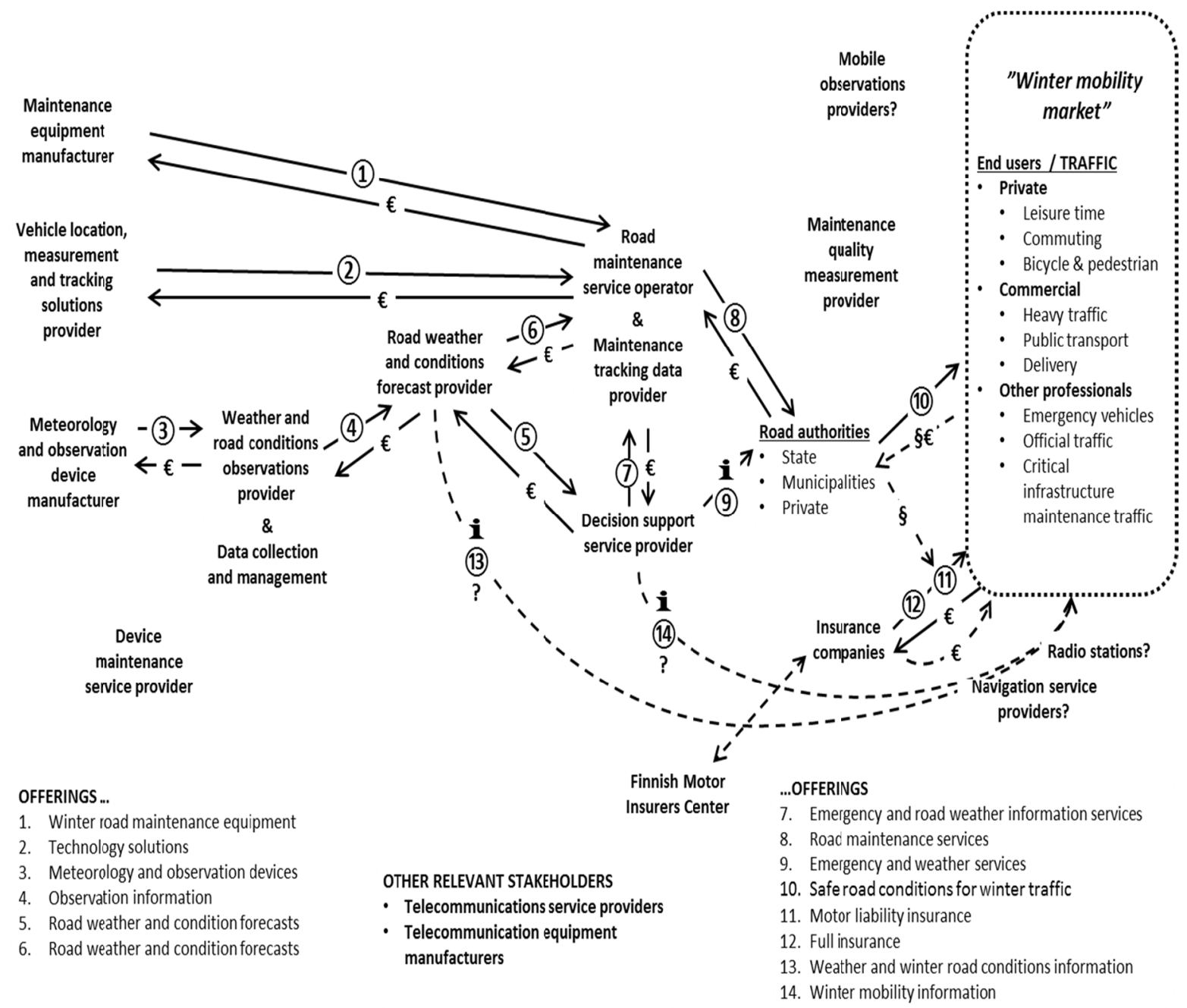

Figure 2. Value network of the Finnish winter maintenance ecosystem

As seen in Table 1, the ecosystem includes both internal and external stakeholders. Adapting Rubenstein-Montano et al. (2001), if development of the ecosystem and its value creation is desired, this will be accomplished in terms of internal stakeholders, because they are the direct and "formal" members of the ecosystem. External stakeholders that are able to change along with the ecosystem will probably benefit indirectly from its development. Thus this development may not necessarily have an explicit impact on their business or business models.

For example, telecommunications equipment manufacturers or telecommunications service providers are good examples of external stakeholders. Although the existing ecosystem is developed, it does not have more than a minor impact on them and their role remains the same. On the other hand, nowadays almost everything is connected and based on ICT technologies. Thus it can be argued that ICT products and services enable the building and development of the ecosystem as a whole and the communications system operators have an intermediating role in the value creation process (Leviäkangas, 2011)

Insurance companies do not directly benefit from the development of the ecosystem or winter road safety. However, safety improvements reduce accidents and reimbursement rates as well, which has a positive impact on the insurance companies' business, at least in the shorter term.

Demand and supply side stakeholders are denoted by letters D and S respectively in Table 1. It should be noted that the table relates only to Finland; in other countries the roles, functions and responsibilities may be divided differently, as would obviously be the case concerning the division between supply and demand. 
Table 1. Roles and functions of stakeholders of the Finnish ecosystem

\begin{tabular}{|c|c|c|}
\hline Stakeholder & Role and function in the ecosystem & Type \\
\hline $\begin{array}{l}\text { Maintenance equipment } \\
\text { manufacturer }\end{array}$ & $\begin{array}{l}\text { Manufacture of road maintenance equipment that can be installed in } \\
\text { road maintenance vehicles, for snow removal, anti-skid treatment } \\
\text { and data logging depending on the functions of the devices. }\end{array}$ & $\begin{array}{l}\text { Internal } \\
(\mathrm{S})\end{array}$ \\
\hline $\begin{array}{l}\text { Vehicle location, } \\
\text { measurement and tracking } \\
\text { solutions provider }\end{array}$ & $\begin{array}{l}\text { Provides systems and solutions for monitoring e.g. the location of } \\
\text { the vehicle, route history, hours of operation. }\end{array}$ & $\begin{array}{l}\text { Internal } \\
(\mathrm{S})\end{array}$ \\
\hline $\begin{array}{l}\text { Meteorology and observation } \\
\text { device manufacturer }\end{array}$ & $\begin{array}{l}\text { Provides a comprehensive range of observation and measurement } \\
\text { products (e.g. road weather stations, RWS) and services for } \\
\text { chosen weather-related markets. }\end{array}$ & $\begin{array}{l}\text { Internal } \\
(\mathrm{S})\end{array}$ \\
\hline $\begin{array}{l}\text { Device maintenance service } \\
\text { provider }\end{array}$ & $\begin{array}{l}\text { Repair services include fault tracing and repair or replacement of } \\
\text { failed RWS and components, and final testing to ensure that the } \\
\text { equipment is functioning properly. }\end{array}$ & External \\
\hline $\begin{array}{l}\text { Road and weather conditions } \\
\text { observations provider \& }\end{array}$ & $\begin{array}{l}\text { Road and weather condition observations are collected and produced } \\
\text { with public funds and are thus freely provided by the Finnish }\end{array}$ & $\begin{array}{l}\text { Internal } \\
(\mathrm{S})\end{array}$ \\
\hline Data collection management & $\begin{array}{l}\text { Meteorological Institute and the Finnish Transport Agency. Data } \\
\text { management is also handled by the organizations. }\end{array}$ & \\
\hline $\begin{array}{l}\text { Road weather and conditions } \\
\text { forecast provider }\end{array}$ & $\begin{array}{l}\text { Offers a wide variety of weather services for commercial shipping, } \\
\text { road maintenance and air traffic using different models, observations } \\
\text { and meteorological expertise. }\end{array}$ & $\begin{array}{l}\text { Internal } \\
(\mathrm{S}, \mathrm{D})\end{array}$ \\
\hline $\begin{array}{l}\text { Decision support system } \\
\text { provider }\end{array}$ & $\begin{array}{l}\text { The system collects and uses current and historical road weather and } \\
\text { pavement information. Allows decision-makers to use a system that } \\
\text { provides guidance as to what to do based on current and predicted } \\
\text { weather. }\end{array}$ & $\begin{array}{l}\text { Internal } \\
(\mathrm{S})\end{array}$ \\
\hline \multirow[t]{3}{*}{$\begin{array}{l}\text { Decision support service } \\
\text { provider (aka Road } \\
\text { Weather/Management } \\
\text { Center) }\end{array}$} & $\begin{array}{l}\text { Monitors weather and road weather conditions. With the help of } \\
\text { accurate and frequently updated weather forecasts, the right } \\
\text { equipment can be sent off to clear the street of snow, ice and slush at } \\
\text { the right time. }\end{array}$ & $\begin{array}{l}\text { Internal } \\
(\mathrm{S}, \mathrm{D})\end{array}$ \\
\hline & $\begin{array}{l}\text { Emergency requests can be transmitted directly to drivers or the } \\
\text { customer's work supervisors as agreed. }\end{array}$ & \\
\hline & $\begin{array}{l}\text { In addition, produces weather and road weather information that can } \\
\text { be used over the Internet. }\end{array}$ & \\
\hline $\begin{array}{l}\text { Road maintenance service } \\
\text { operator \& Maintenance } \\
\text { tracking data provider }\end{array}$ & $\begin{array}{l}\text { Undertakes maintenance operations according to agreements with } \\
\text { road authorities/infrastructure owners. Keywords in winter } \\
\text { maintenance are the anticipation of road weather conditions, } \\
\text { selection of the right measures and their correct timing. Anticipation } \\
\text { prevents worsening of road weather conditions and reduces the need } \\
\text { for preventive actions. Correct timing of tasks also improves the } \\
\text { economic efficiency of operations. }\end{array}$ & $\begin{array}{l}\text { Internal } \\
(\mathrm{S})\end{array}$ \\
\hline Road authority/owner & $\begin{array}{l}\text { The main purpose is to keep roads usable every day and ensure that } \\
\text { traffic can flow safely. The owners are responsible for maintaining } \\
\text { roads plus adjoining structures, bus stops and road lighting. } \\
\text { Nowadays the maintenance is usually outsourced. }\end{array}$ & $\begin{array}{l}\text { Internal } \\
(\mathrm{D})\end{array}$ \\
\hline $\begin{array}{l}\text { User of road and } \\
\text { infrastructure }\end{array}$ & $\begin{array}{l}\text { End users (private people, commercial and other professional users) } \\
\text { are those who use the infrastructure and for whom it is maintained. }\end{array}$ & $\begin{array}{l}\text { Internal } \\
(\mathrm{D})\end{array}$ \\
\hline Insurance company & $\begin{array}{l}\text { Provides e.g. compulsory motor liability insurance for a vehicle used } \\
\text { in traffic. Generally insurance premiums are directly related to safety } \\
\text { statistics. }\end{array}$ & External \\
\hline $\begin{array}{l}\text { Finnish Motor Insurers } \\
\text { Center }\end{array}$ & A cooperation body of Finnish motor insurers. & External \\
\hline $\begin{array}{l}\text { Telecommunications service } \\
\text { provider }\end{array}$ & Provides telecommunications services for consumers and businesses. & External \\
\hline $\begin{array}{l}\text { Telecommunications } \\
\text { equipment manufacturer }\end{array}$ & $\begin{array}{l}\text { Offers network products that give the ability to connect (voice, data, } \\
\text { images or video) and to share ideas and information anytime and } \\
\text { anywhere. }\end{array}$ & External \\
\hline
\end{tabular}




\subsection{Social Benefits of Winter Maintenance}

Bläsche et al. (2011) identify snowfall, low temperatures and blizzards as the most significant extreme weather phenomena related to winter road transport. The main impacts of these conditions are longer travel times, an increased risk of accidents and reduced accessibility of the road network. Strong et al. (2010) have found that adverse weather conditions reduce traffic speed and increase the frequency of crashes while decreasing the number of fatal crashes.

Road weather solutions that collect, refine, and/or distribute information to road users and to maintenance actors can provide significant societal benefits by mitigating these impacts as identified by e.g. Pilli-Sihvola et al. (2012).

Fabre and Klose (1992) maintain that the estimation of costs and benefits of a road weather information system should take into account road maintenance activities, driving costs, and environmental, social and psychological effects. They see that the most important benefit of RWIS is the possibility of anticipating icy road surface conditions and eliminating accidents caused by slipperiness by responding to poor road conditions more quickly. Additional benefits can be gained from improved maintenance methods through more efficient distribution of work and personnel and reduced use of maintenance materials. Leviäkangas and Hietajärvi (2010) compiled a summary of road weather information services and RWIS benefits, which showed typically clear positive benefit-cost ratios.

However, aside from information benefits, the benefits of actual maintenance operations have been studied much less, although a few early studies can be found. A report by the Finnish National Road Administration (1993) assessed the benefits of the road weather information system taken into use in Finland in 1987-1992. Time savings from de-icing activities were estimated to be 23 minutes per activity on average. With an average accident cost of FIM 300000 and presumed change in accident risk (between icy and dry conditions) of 5.8 accidents / $1000000 \mathrm{~km}$, the annual benefits due to quicker maintenance operations in the Kymi road district were found to be as follows:

- $\quad$ Accident cost savings - FIM 4.2M (MEUR $\sim 0.7$; EUR $1 \approx$ FIM 6 )

- $\quad$ Time cost savings - FIM 0.3M (MEUR $\sim 0.05$ )

- Vehicle cost savings -FIM 0.1 (MEUR $\sim 0.002)$

This adds up to total benefits of about FIM 4.6M (MEUR 0.752) in 1993 currency. At that time, the Kymi district was responsible for approximately $7 \%$ of the main roads in Finland.

The report by the Finnish National Road Administration (1993) also describes a pilot in 1991-1992 in the southern region of the Turku district, where a centralized road weather center was tested. In the centralized road weather center concept, road conditions are remotely monitored at a single centralized location. In normal conditions, on-duty staff was not sent out on the roads. In more difficult conditions, regional on-duty staff was called in to monitor the conditions on the road. Estimates of the resulting savings in personnel costs ranged from FIM $0.5 \mathrm{M}$ to FIM 1.0M, but these results applied to the historical situation when the road authority was an integrated entity, i.e. taking care also of the operational snow removal, de-icing and other winter maintenance. By 1995, the road weather center model was in use nationally by the Finnish Road Administration.

\subsection{Value Capture Strategies for the Business Ecosystem}

Various methods exist for developing road winter maintenance ecosystems. However, to enhance and co-create the value, joint development of the ecosystem has been seen as the best value capturing strategy so far. Joint development is a strategy that offers synergic benefits for the ecosystem by combining the services or knowhow of different stakeholders into a sophisticated entity. In this sense, successful joint development may improve market efficiency by better linking the costs and benefits of road winter maintenance improvements.

In the existing ecosystem, five ecosystem stakeholders (meteorological observation device manufacturer, maintenance equipment manufacturer; vehicle location, measurement and tracking solutions provider; meteorology and observation device manufacturer; and road weather and conditions forecast provider) have seen the potential of carrying out some joint development activities and thus deepening their business relationships. The overall idea is to enhance the development of a next generation decision support system (DSS) that offers accurate and the most recent possible road weather and condition information, thus helping the decision support service provider to deliver better information and recommendations for road maintenance service operators. It is worth noting that taking such a step requires ecosystem members to pull together rather than relying on the trendsetting of lead companies. 
The existing DSS acts as a premise for the new system. At present the existing system cannot exploit the incoming information as well it could, or the information is inadequate. Therefore the objective set for the new DSS is to collect the necessary information from those with the most favorable conditions, and finally analyze and refine it in the new system. This approach also enables every participant to focus on their core business and development.

In the new system the role of the decision support system provider remains roughly the same, still focusing on providing road condition forecasts. However, the current ecosystem has some overlap because the weather forecast provider also offers road condition forecasts, although this is not their core business. Thus the two players have decided that the latter will concentrate on weather forecasts while the former continues its focus on road condition forecasts.

Additionally, the maintenance equipment manufacturer has equipped their latest models with different kinds of technology, sensors and meters that collect data during maintenance (e.g. location, friction, temperature, de-icing, performed maintenance activities). Therefore they can provide real-time information about the weather and road conditions to the new DSS. Naturally, the more comprehensive equipping of maintenance equipment increases the demand for sensors and technology and hence provides wider markets for the vehicle location, measurement and tracking solutions provider and meteorological observation device manufacturer.

According to these five stakeholders, the most optimal situation would be for the road authorities or state to procure the new DSS when it is ready. Thus large-scale deployment and usage of the system would be more likely, ultimately manifesting itself in a safer and more reliable mobility market. At the same time, the ecosystem stakeholders could develop the ecosystem further. The risk, however, is that public procurement practices require splitting bids into smaller contracts, which inflates the system packaging efforts of the ecosystem. Hence public sector clients face the difficult dilemma of how to boost innovation and take systems to a new level while maintaining market neutrality and not favoring any given ecosystem over another. Inevitably, there will be pros and cons to whichever direction is taken.

\section{Conclusion and Discussion}

The conclusions are drawn from our case analysis of the Finnish winter maintenance ecosystem, and from some of the more generic studies on ecosystems. Studies on road weather information systems also contributed. We postulate the following:

\section{Business ecosystems are vital in order to deliver not only market-demanded services but also services that are} regarded as societal and public.

It seems that the more functions an ecosystem is able to provide, the better prospects there are to integrate these functions into service packages that take service and the satisfaction of user needs to a newer level. Especially in smaller markets, such as Finland, the demand is restricted and the public procurement standards are very specific, even to the extent that it has been identified as a bottleneck for new innovations, and public procurement is set on a high priority in boosting them. This is done not only at national but also at EU level (see e.g. Government of Finland, 2008; European Commission, 2010).

For a winter road maintenance ecosystem such policies are truly good news, but according to our observations, the distance between 'policy talk' and 'practice' is somewhat obvious. Years after the national and EU-level declarations, the practices of public procurement remain relatively unchanged, at least in Finland. Our perception is that there are major differences between countries in how they apply public procurement and how successful they are in this with regard to development of competitive business ecosystems, not only for their domestic markets but also for international competition.

The conclusion on the relevance of public procurement places high expectations on public officials who should at the same time ensure high quality services with acceptable price and facilitate innovation. The risks of innovation procurement are evident, yet few public managers are rewarded for such risk taking. It seems that public sector management systems are lagging behind the technological evolution and changing market conditions. However, the public sector needs capable ecosystems, as they are reducing their operational functions and increasingly relying on the private sector's ability (and willingness) to provide services either through contracts with the public sector or purely market demand.

\section{Even small firms that have unique capabilities (offerings) can have a key role in a business ecosystem.}

This postulate is self-evident but is extremely relevant in a small-market context, where most of the firms are small anyway. Where niche areas, as winter road maintenance inevitably is, are concerned, the second postulate is well understood. Friction measuring technologies, precise road condition prediction models, and a dedicated 
on-the-road fleet are all examples where this uniqueness can be found. This postulate, if true, will open opportunities for small innovative entrepreneurs that can find profitable 'boxes' from larger ecosystems.

For larger firms the capabilities can, apart from technology, be related e.g. to the market position and customer base. This is exactly the situation with the Finnish winter road maintenance business ecosystem. One world leading company sought a partnership with smaller companies to create service packages and systems that are diversifying from the mainstream offerings of its competitors.

\section{The capabilities of ecosystems define the service levels and societal gains.}

The ecosystems' capabilities, their offerings, and their coherence in sharing common objectives in the provision of services define how good the services are in the end. The coherence is not only about risk and revenue sharing agreements between the supply side of the ecosystem, but also about coherence in client-supplier interfacing. This means that contract models, business models of suppliers, and successful managerial control on issues that are the elements of good service must go hand in hand. Thus it is not only the business players who must play together toward a common goal, it is also the public side. Conflicting interests are inevitably there, but these must be managed on both sides, as well as within the supply and demand side.

For the winter road maintenance ecosystem, contractual arrangements are of paramount interest. Performance based contracts, quality and service level measurement and rewarding mechanisms are intuitively some of those aspects that will have an impact on service levels and how well the level of service is understood by all parties. The more transparent the framework for service quality management is, the greater will be the likelihood of success.

From the technological viewpoint, novel service concepts will likely demand new technological solutions, both at component and system levels. This in turn is facilitated when performance type contracts are adopted. Process based contracts, as has often been repeated, have a tendency to place more emphasis on process efficiency enhancement rather than on underscoring service levels and value for money. And the latter is exactly what healthy ecosystems should be looking for.

\section{The emergence and success of ecosystems is a dynamic process requiring a multifaceted responsiveness.}

Here we mean that, as stated earlier, the emergence and nurturing of ecosystems requires effort on both sides, both demand and supply. Contractual models are a typical example of this. However, there are further facets to this development. One of the typical mindsets of corporate managers is that their company is on its own and must survive competition against others. This may be the case, but if ecosystems are truly to emerge more extensively, the mindset of managers must focus more on partner seeking and alliance building. No company alone can, for example, offer "everything on winter road maintenance", at least not if we understand the concept as a full-scale management of winter road conditions. Wide-covering contracts are possible, but for example meteorological observations and expertise in interpreting and forecasting road weather conditions must be sought outside road maintenance companies, no matter how diversified they are. Winter road maintenance is and will remain a group endeavor.

As previously mentioned, technology changes must be reacted to and responded to. These changes can be either opportunities or threats to individual companies or even existing ecosystems. Technological drivers are particularly relevant, as they tend to quickly affect engineering businesses, even if winter road maintenance is seldom perceived as a fast-pace tech biz. However, it could well be that. The push in technology will pose managerial challenges in conventional engineering fields, and not only on the private side. Each forward-looking transport agency or road authority should consider having a CTO on their management board.

Finally, as with each product or service, each ecosystem and its services must pass the ultimate market test, the end user. Unless road users (consumers) are 'buying' the service it is difficult to see that an ecosystem would have a promising future. Even if the end customers are not directly paying for the services, in the current world of open media, dissatisfaction will relay to a wider audience and local decision makers.

\section{Acknowledgements}

The authors would like to thank the National Technology Agency (Tekes), FIRWE companies, VTT Technical Research Centre of Finland and VTT Graduate School for financing this research work.

\section{References}

Bläsche, J., Kreuz, M., Mühlhausen, T., Schweighofer, J., Leviäkangas, P., Molarius, R., ... Ludvigsen, J. (2011). Consequences of extreme weather. Retrieved from http://ewent.vtt.fi/Deliverables/D3/EWENT_D34 _v1_0_20111201.pdf 
Cleland, D. I. (1986). Project Stakeholder Management. Project Management Journal, 17(4), 36-44.

Donaldson, K. M., Ishii, K., \& Sheppard, S. D. (2006). Customer Value Chain Analysis. Research in Engineering Design, 16, 174-183. http://dx.doi.org/10.1007/s00163-006-0012-8

European Commission. (2010). Europe 2020 Flagship Initiative. Innovation Union. Communication from the commission to the european parliament, the council, the european economic and social committee and the committee of the regions. sec(2010) 1161, Brussels, 6.10.2010, $\operatorname{COM}(2010) 546$ final.

Fabre, F., \& Klose, A. (1992). Cost 309: Road weather conditions. Transport-Research, EUR 13847 EN. Commission of the European Communities. Luxembourg.

Finnish National Road Administration. (1993). Tiesääjärjestelmän rakentaminen 1987-1992 [The development of the road weather information system 1987-1992 - in Finnish]. Kymi road district, Finnish National Road Administration, Kouvola.

Freeman, E. R. (1984). Strategic Management: A Stakeholder Approach. New York, NY: Pitman Publishing Inc.

Government of Finland. (2008). Government's Communication on Finland's National Innovation Strategy to the Parliament. Helsinki.

Gruening, G. (2001). Origin and theoretical basis of New Public Management. International Public Management Journal, 4, 1-25. http://dx.doi.org/10.1016/S1096-7494(01)00041-1

Herrala, M., Leviäkangas, P., \& Haapasalo, H. (2009). Information Value Attributes and Assessment Methods A Construct from Traffic and Traveller Information Perspective. Value World, 32(1), 34-45.

Iansiti, M., \& Levien, R. (2004a). The keystone advantage: What the new dynamics of business ecosystems mean for strategy, innovation and sustainability. Boston, MA: Harvard Business School Press.

Iansiti, M., \& Levien, R. (2004b). Strategy as ecology. Harvard Business Review, 82(3), 68-78.

Leviäkangas, P. (2011). Building Value in ITS Services by Analysing Information Service Supply Chains and Value Attributes. International Journal of Intelligent Transport Systems Research, 9(2), 47-54. http://dx.doi.org/10.1007/s13177-011-0029-x

Leviäkangas, P., \& Ojala, L. (2011). PPP Research Issues in Finland - What's Up and What's Next. Public Private Partnerships in Transport: Trends \& Theory. COST Action 1001 Symposium, Lisbon, 12 January 2011.

Leviäkangas, P., Molarius, R., Könönen, V., Hietajärvi, A. -M., \& Zulkarnain (2013). Devising and Demonstrating an Extreme Weather Risk Indicator for Transportation System. Transportation Research Record, Journal of the Transportation Research Board, 2329, 45-53. http://dx.doi.org/10.3141/2329-06

Leviäkangas, P., Nokkala, M., Rönty, J., Talvitie, A., Pakkala, P., Haapasalo, H., ... Finnilä, K. (2011). Ownership and governance of Finnish infrastructure networks. VTT Publications 777. VTT, Espoo, 2011.

Leviäkangas, P. -M \& Hietajärvi, A. -M. (2010). Weather information for transport - the value shift. Value World, 33(2), 4-13.

Molarius, R., Könönen, V., Leviäkangas, P., Zulkarnain, \& Rönty, J. (2013). The Extreme Weather Risk Indicators (EWRI) for European transport system. Natural Hazards. Springer. http://dx.doi.org/10.1007/s11069-013-0650-x

Moore, J. F. (1993). Predators and prey: A new ecology of competition. Harvard Business Review, 71(3), 75-86.

Murman, E., \& Allen, T. (2002). Lean Enterprise Value: Insights from MIT's Lean Aerospace Initiative. New York, NY: Palgrave.

Peltoniemi, M. (2006). Preliminary theoretical framework for the study of business ecosystems. Emergence: Complexity \& Organization, 8(1), 10-19.

Pilli-Sihvola, E., Leviäkangas, P., \& Hautala, R. (2012). Better winter road weather information saves money, time, lives and the environment. In Proceedings of the 19th ITS World Congress, Vienna, Austria, October 22-26. ERTICO (ITS Europe).

Ramaswamy, V., \& Gouillart, F. (2010). The power of co-creation: Build it with them to boost growth, productivity, and profits. New York, NY: Free Press.

Ritchey, T. (2002). Modelling Complex Socio-Technical Systems Using Morphological Analysis. Adapted from an address to the Swedish Parliamentary IT Commission, Stockholm, December 2002. Retrieved from 
http://www.swemorph.com/pdf/it-webart.pdf

Rubenstein-Montano, B., Liebowitz, J., Buchwalter, J., McCaw, D., Newman, B., \& Rebeck, K. (2001). A systems thinking framework for knowledge management. Decision Support Systems, 31(1), 5-16. http://dx.doi.org/10.1016/S0167-9236(00)00116-0

SAVE International. (2007). Value Standard and Body of Knowledge. SAVE International Value Standard, 2007 edition.

Strong, C. K., Ye, Z., \& Shi, X. (2010). Safety Effects of Winter Weather: The State of Knowledge and Remaining Challenges. Transport Reviews, 30, 677-699. http://dx.doi.org/10.1080/01441640903414470

Walter, A., Ritter, T., \& Gemünden, H. G. (2001). Value creation in buyer-seller relationships. Industrial Marketing and Management, 30, 365-377. http://dx.doi.org/ 10.1016/S0019-8501(01)00156-0

Weiller, C., \& Neely, A. (2013). Business model design in an ecosystem context. University of Cambridge, Cambridge Service Alliance.

Winch, G. M. (2004). Managing project stakeholders. In P. W. G. Morris, \& J. K. Pinto (Eds.), The Wiley guide to managing projects (pp. 321-329). New Jersey: Wiley.

Yourdon, E. (1989). Modern Structured Analysis. Upper Saddle River, NJ: Yourdon Press.

Zulkarnain, \& Leviäkangas, P. (2012). The size, structure and characteristics of Finland's ITS industry. Technology \& Investment, 3(3), 158-167. http://dx.doi.org/10.4236/ti.2012.33022

\section{Copyrights}

Copyright for this article is retained by the author(s), with first publication rights granted to the journal.

This is an open-access article distributed under the terms and conditions of the Creative Commons Attribution license (http://creativecommons.org/licenses/by/3.0/). 